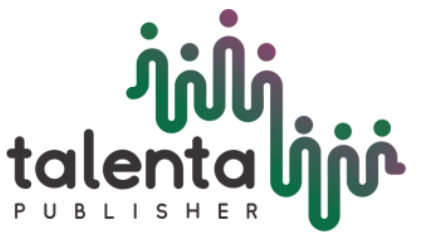

\title{
Effects of TESPT-Silane Coupling Agent on Torque Properties and Degree of Filler Dispersion of Silica Filled Natural Rubber and Epoxidized Natural Rubbers Compounds
}

\author{
Indra Surya ${ }^{1}$, and Nabil Hayeemasae ${ }^{2}$ \\ ${ }^{1}$ Department of Chemical Engineering, Universitas Sumatera Utara, Medan, 20155, Indonesia \\ ${ }^{2}$ Department of Rubber Technology and Polymer Science, Faculty of Science and Technology, Prince of \\ Songkla University, Patani Campus, 94000, Pattani, Thailand
}

\begin{abstract}
The effect of the addition of a bis(triethoxysilylpropyl) tetra sulphide or TESPTsilane coupling agent on torque properties and degree of filler dispersion of silica-filled compounds of natural rubber (NR), epoxidized natural rubbers with $25 \%$ mole of epoxidation (ENR 25) and epoxidized natural rubbers with $50 \%$ mole of epoxidation (ENR 50) were investigated. All the rubbers were filled by silica filler at a fixed loading (30.0 parts per hundred rubber, phr) and the TESPT was added to each silica-filled rubbers compounds at 1.0phr. It was found that TESPT affected the torque properties of all the silica-filled rubbers compounds. The TESPT decreased the minimum torque of NR system but increased the minimum torque of ENRs systems and maximum and torque differences of the all rubbers systems. The minimum torque was decreased from 0.61 to $0.53 \mathrm{dN} . \mathrm{m}$ for $\mathrm{NR}$; were increased from 0.23 to $0.49 \mathrm{dN} . \mathrm{m}$ for ENR 25 and from 0.07 to $0.34 \mathrm{dN} . \mathrm{m}$ for ENR 50.It was also found that the TESPT acted as an internal plasticizer for NR which improved the degree of silica dispersion. Presumably, for the ENRs, the TESPT acted as an additional cross linker with a more pronouncedly which poorer the degree of silica dispersion.
\end{abstract}

Keywords: Torque properties, TESPT, Silica, Degree of filler dispersion

\begin{abstract}
Abstrak. Pengaruh penambahan suatu bahan bis(triethoxysilylpropyl) tetrasulphide atau bahan penggandeng TESPT terhadap sifat-sifat tork dan derajad penyerakan pengisi dari kompon-kompon terisi silika dari karet alam (KA), karet-karet alam terepoksidasi 25 persen mol (KAT 25) dan 50 persen mol (KAT 50). Kesemua jenis karet tersebut terisi silica dengan kadar 30.0 bagian per seratus bagian karet, bsk) dan TESPT ditambahkan kemasing-masing kompon-kompon karet terisi silica dengan kadar 1.0 bsk. Ditemukan bahwa TESPT berpengaruh kepada sifat-sifat tork dari semua jenis kompon karet terisi silica tersebut. TESPT menurunkan tork minimum dari sistim KA tetapi menaikkan tork minimum sistim-sistim KAT, tork maksimum dan selisih tork dari kesemua sistim karet. Tork minimum turun dari 0.61 ke 0.53 dN.m untuk KA; naik dari 0.23 ke 0.49 dN.m untuk KAT 25 dan dari 0.07 ke 0.34 dN.m untuk KAT 50. Diketemukan juga, TESPT bertindak sebagai bahan pemplastik internal untuk KA yang meningkatkan derajad penyerakan silika. Diasumsikan untuk KAT 25 dan KAT, TESPT bertindak lebih sebagai bahan penyambungsilang tambahan yang menurunkan derajad penyerakan silika.
\end{abstract}

\footnotetext{
*Corresponding author at: Department of Chemical Engineering, University of Sumatera Utara, Jl. AlmamaterKampus USU Medan, 20155, Sumatera Utara, Indonesia
}

E-mail address: indradanas@yahoo.com 
Kata kunci: Sifat-sifat tork, TESPT, Silika, Derajat penyerakan pengisi

Received 13 August 2019| Revised 27September 2019| Accepted 27September 2019

\section{$1 \quad$ Introduction}

It is very common in rubber technology utilising reinforcing fillers in producing rubber products with a satisfactory level of life service and strength [1]. Besides carbon blacks (CBs), silicas of varying forms and particles-sizes have been widely used as reinforcing fillers in rubber industry nowadays. Generally, the properties of silica-reinforced rubbers are usually inferior to those of CBs, even when they are of comparable size [2]. It is due to the apparent dissimilarity of surface chemistry of both of them. Each type of filler produces useful rubber properties as a result of its specific surface chemistry. However, due to the polar nature and relatively inert nature of its surface, silica provides a unique combination of tear strength, abrasion and age resistances and also adhesion properties [3].

The main application of silica is in product where black colour is not a requirement e.g. shoe soles [4]. It is also used, in combination with $\mathrm{CB}$, in chip-and cut-resistance tyres for earthmovers and mining vehicles. Due to the presence of numerous silanol groups on its surface, silica is a highly polar material and can readily interact with zinc oxide during curing. The silica bound zinc unable to activate the accelerator. Consequently, zinc activity reduced, the sulphur reaction is retarded [5].

The surface properties of silica cause several difficulties in using it as reinforcing filler, particularly in hydrocarbon rubbers such as natural rubber (NR). The surface of silica is highly polar and hydrophilic as the presence of numerous silanol groups. These silanol groups relatively incompatible with $\mathrm{NR}$, and interaction between them is weak. On the other hand, the silica particles tend to interact with each other to form aggregates. Since the silica to NR interaction weaker than the silica to silica interaction; the results are the formation of large agglomerates, poor dispersion of silica [1].

Organosilanes are utilized to improve silica to rubber interaction of the silica-filled rubbers and consequently enhance the reinforcing effect of the silica [6]. Organosilanes are reactive additives, and usually utilized in a small quantity, less than $2 \mathrm{phr}$ [7]. The organosilanes modify the surface of silica [8]. The modified silica provides a chemically active surface that can participate in vulcanization, providing coupling bonds between organosilane and both the silica and the rubber phases [9]. There is much evidence [10] confirming the existence of such bonds. In all these cases marked improvement in rubber properties was noted [11].

This study reports the effort in improvement in degree of filler dispersion of silica filled-natural and epoxidized natural rubbers through the use of a commercial coupling agent. The 
bis(triethoxysilylpropyl) tetra sulphide or TESPT silane coupling agent was chosen as the commercial coupling agent.

\section{Experimental}

\subsection{Materials}

NR grade SMR-L was obtained from Guthrie (M) Sdn. Bhd., Seremban, Malaysia, and epoxidized natural rubber with 25 and 50 moles\% epoxidation (ENR 25 and ENR 50) were supplied by the Rubber Research Institute Malaysia (RRIM). Other compounding ingredients, such as sulphur, zinc oxide, stearic acid, N-isopropyl-N'-phenyl-p-phenylenediamine (IPPD), precipitated silica, benzothiazolyldisulfide (MBTS) and TESPT were supplied by the rubber lab of Universiti Sains Malaysia (USM), Malaysia.

\subsection{Compounding}

A semi-efficient vulcanisation system was applied for the compounding. The compounding procedure was performed on a two-roll mill (Model XK-160). Table 1 displays the compound formulation of silica-filled rubbers compounds without and with TESPT.

Table 1. The formulation of silica-filled rubbers compounds without and with TESPT

\begin{tabular}{lrr}
\hline Ingredients & Control (phr)* & With TESPT (phr)* \\
\hline SMR-L, ENR 25 or ENR 50 & 100.0 & 100.0 \\
ZnO & 5.0 & 5.0 \\
Stearic acid & 2.0 & 2.0 \\
IPPD & 2.0 & 2.0 \\
MBTS & 1.5 & 1.5 \\
Silica & 30.0 & 30.0 \\
TESPT & 0.0 & 1.0 \\
\hline
\end{tabular}

*parts per hundred rubber

\subsection{Torque properties}

The torque properties were obtained through the cure characteristics test of the silica-filled rubbers compounds using a Monsanto Moving Die Rheometer (MDR 2000), which was employed to determine the minimum torque $\left(\mathrm{M}_{\mathrm{L}}\right)$, maximum torque $\left(\mathrm{M}_{\mathrm{H}}\right)$ and torque difference $\left(\mathrm{M}_{\mathrm{H}}-\mathrm{M}_{\mathrm{L}}\right)$, according to ISO 3417. Samples of the respective silica-filled rubbers compounds were tested at $150^{\circ} \mathrm{C}$. 


\section{$3 \quad$ Results and Discussion}

\subsection{The torque properties of silica-filled NR and ENRs compounds}

The minimum torques of silica-filled NR, ENR25 and ENR 50 compounds without and with TESPT are shown in Fig. 1. The one phr-TESPT additions into each control compounds affected the minimum torque. The minimum torque of ENRs with TESPT was higher compared to their control ones, whilst the minimum torque of NR with TESPT was lower compared to its control compound. The minimum torque reflects both the filler-filler agglomeration and viscosity of a rubber compound [12]. A lower minimum torque indicates a lower viscosity and weaker filler to filler interaction [1]. For NR; the TESPT decreased the minimum torque and hence, causing easier the effort in dispersing the silica filler. In this case, the TESPT could be considered as an internal plasticizer for NR.

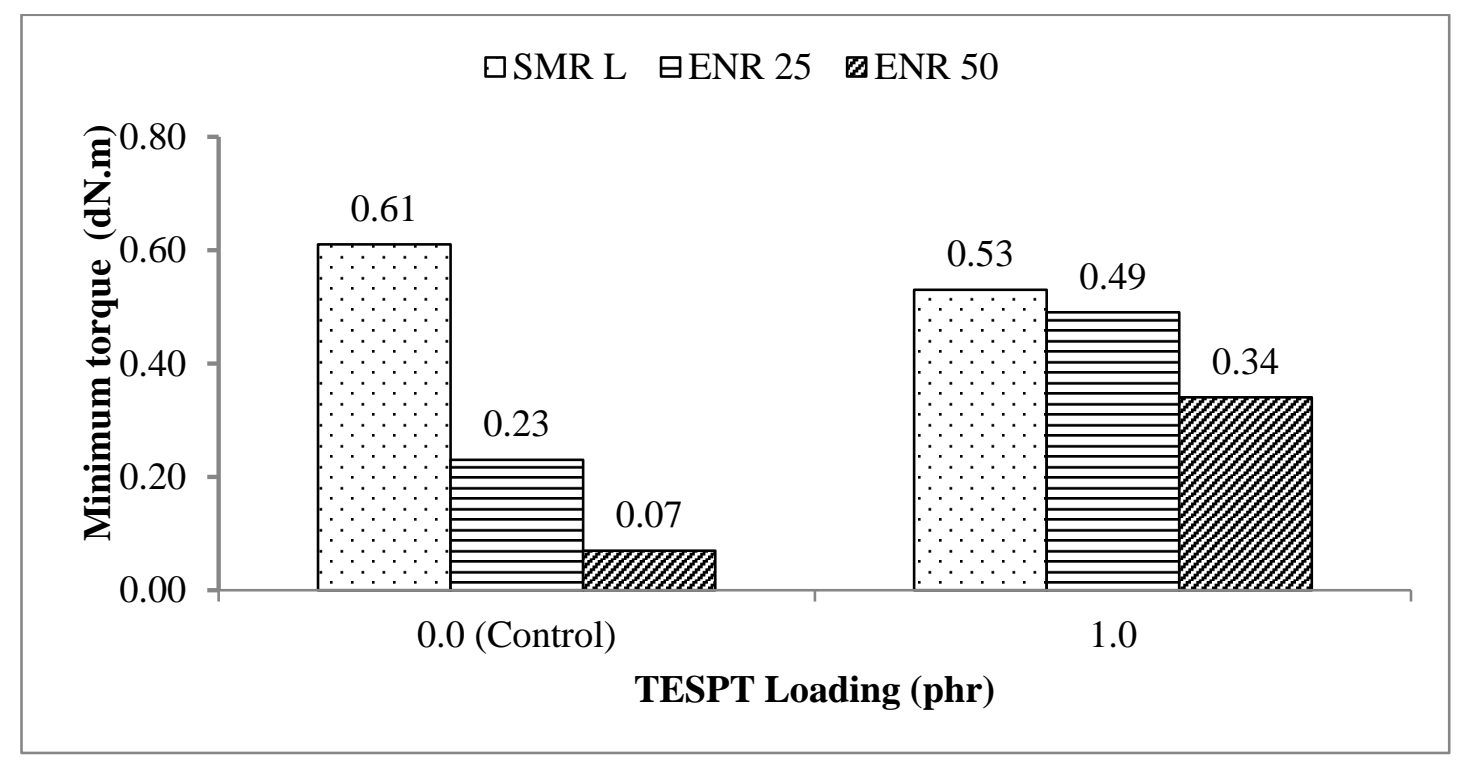

Figure 1. The effect of TESPT on the minimum torque of silica-filled SMR-L and

ENRs compounds.

The enhancement in minimum torque for the ENRs most probably was due to the formation of some premature crosslinks during compounding. The ENRs are active/polar rubbers due to the presence of epoxy groups on their molecules. The TESPT is also an active ingredient for ENRs, especially. Presumably, the epoxy groups and TESPT interacted and reacted chemically that formed another type of crosslink. In this case, the TESPT could be considered as a curative agent for the ENRs.

Fig. 2 shows the maximum torques of silica-filled NR, ENR25 and ENR 50 compounds without and with TESPT. The TESPT affected the maximum torque. The maximum torque of all the rubber compounds was higher compared to their control ones. The maximum torque correlates to the measurement of stock modulus [13] which was increased in this case. It was attributed to 
the improvement of rubber to filler interaction. The TESPT could be considered as a compatibilizer for the silica-filled NR and ENRs compounds.

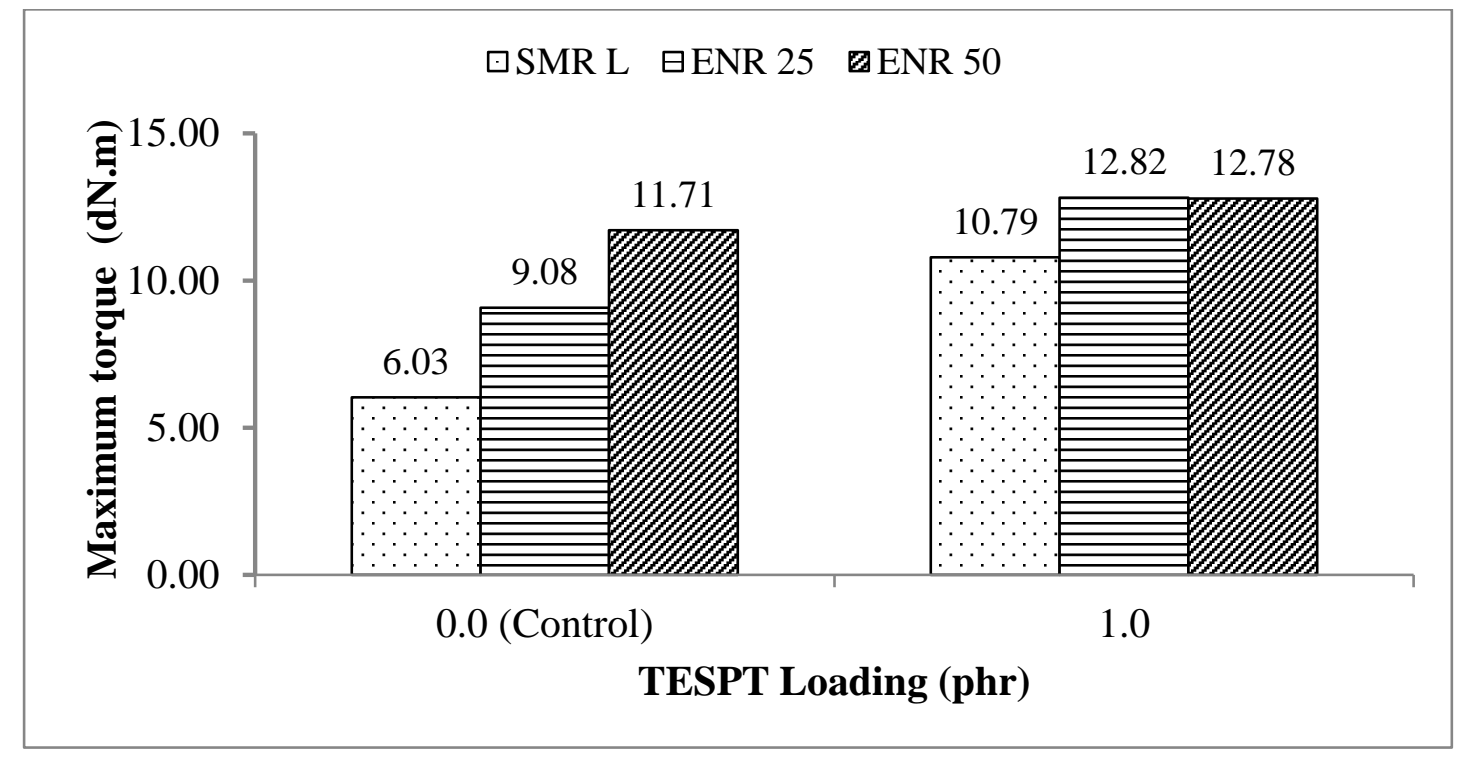

Figure 2. The effect of TESPT on maximum torque of silica-filled SMR-L and ENRs compounds.

Figure 3 shows the torque difference (maximum torque minus minimum torque) of the three types of silica-filled rubbers compounds without and with TESPT. The TESPT increased the torque difference. At a similar silica loading, the torque differences of ENRs were higher than that of NR. It was due to ENRs to silica interaction which formed silanol-epoxy bond, as visualised in Scheme 1 [14]. Presumably, this type of interaction increased the crosslink density of the ENRs systems. The torque difference value is used to indicate the degree of crosslink density of a rubber compound [13]. A greater value indicates a higher degree of crosslink density.

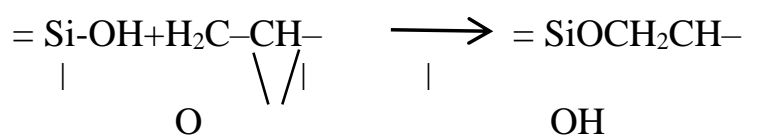

(Scheme 1)

(Silanol group) (Epoxy group) (Silanol-epoxy bond)

The torque difference of ENR 50 was higher compared to ENR 25. It was due to a more epoxy groups of ENR 50 and as a consequence, the crosslink density of ENR 50 was higher also.

As discussed previously, the TESPT increased the degree of crosslink density of the silica-filled NR and ENRS compounds. It was due to the additional function of the TESPT, as an internal plasticizer agent, for NR compound which plasticized and softened the filled NR compound. This resulted in decreasing in viscosity and improvement in process ability of the silica dispersion and NR to silica interaction, respectively. The NR to silica interaction can be 
considered as additional physical crosslink, and together with sulphide crosslinks contribute to total crosslink density [13].

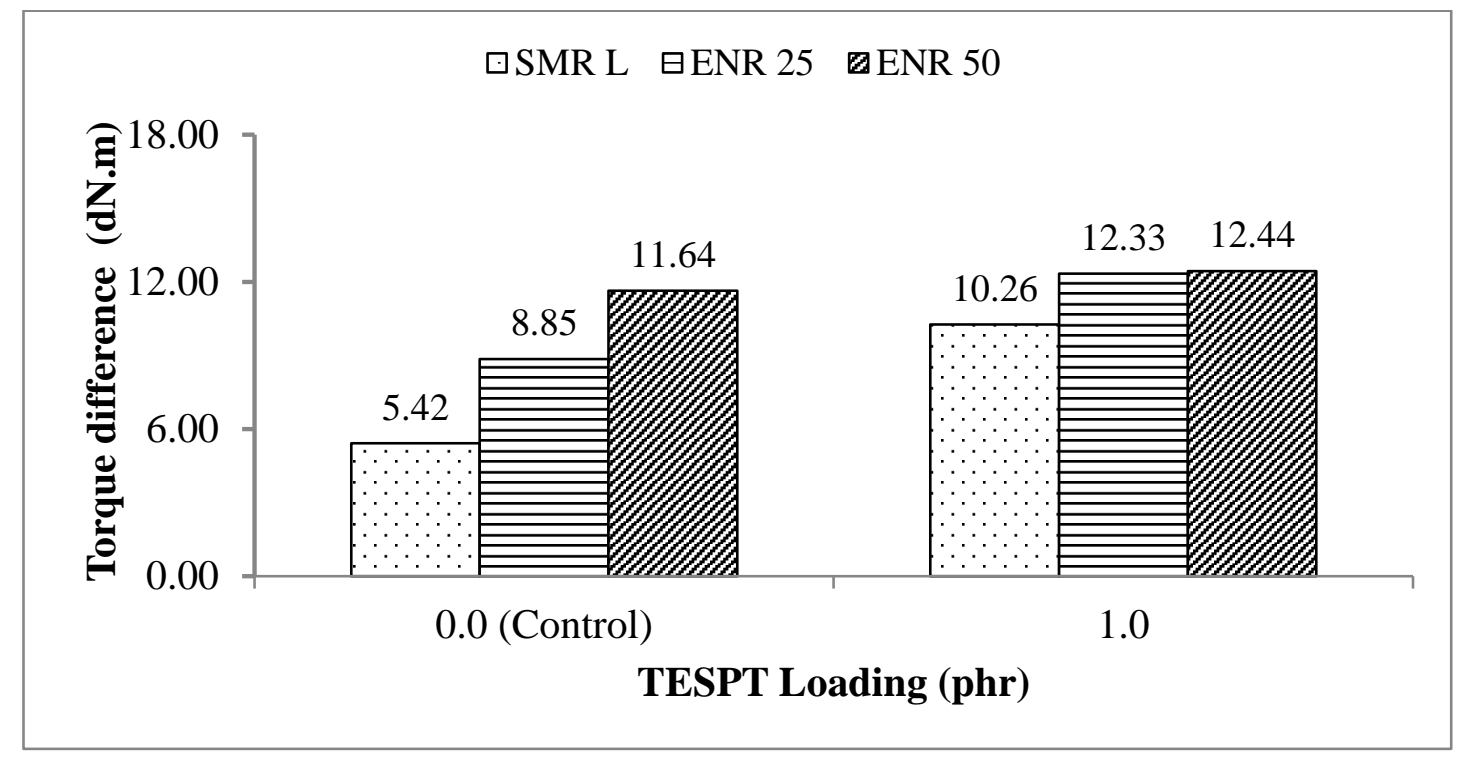

Figure 3. The effect of TESPT on torque difference of silica-filled SMR-L and ENRs compounds.

The TESPT further increased the crosslink density through the formation of some chemical bonds of between TESPT and silanol-epoxy. Presumably, the hydroxyl groups of intermediate silanol-epoxy reacted with TESPT formed some new additional crosslink [15].

At a similar TESPT loading, the torques differences of ENRs were higher than that of NR; the ENR 50 possessed the highest torque difference when compared to the NR and ENR 25. It was due to the highest degree of sulphide, physical and additional crosslinks altogether of ENR 50.

\subsection{The degree of silica dispersion of NR and ENRs compounds}

Based on the torques properties as shown in Figs. 1-2, especially; the degree of silica dispersion in the three types of rubbers compounds, due to the addition of TESPT, were determined using Equation (1) [16].

$$
\mathrm{L}=\eta_{\mathrm{r}}-\mathrm{m}_{\mathrm{r}}
$$

where: $\eta_{\mathrm{r}}=\left[\mathrm{M}_{\mathrm{Lf}} / \mathrm{M}_{\mathrm{Lg}}\right]$, and $\mathrm{m}_{\mathrm{r}}=\left[\mathrm{M}_{\mathrm{Hf}} / \mathrm{M}_{\mathrm{Hg}}\right]$; where $\mathrm{M}_{\mathrm{Lf}}$ and $\mathrm{M}_{\mathrm{Hf}}$ were the minimum and the maximum torques of the filled compounds; and $\mathrm{M}_{\mathrm{Lg}}$ and $\mathrm{M}_{\mathrm{Hg}}$ were the minimum and the maximum torques of the gum or unfilled rubber compound. A lower value of $\mathrm{L}$, at a particular silica loading, means a better degree of silica dispersion.

The $\mathrm{L}$ values of silica in the rubbers systems are shown in Fig. 4. As can be seen, The L value of NR with TESPT was lower compared to NR without TESPT; whilst the ENRs with TESPT had higher L values compared to ENRs without TESPT. For NR, it was due to the plasticizing effect of TESPT on the NR. The TESPT decreased viscosity and hence, improved degree of 
silica dispersion. For ENRs, it was due to the additional cross linker effect of TESPT which some formed additional cross links to the ENRs -silica systems and hence, increased their L values.

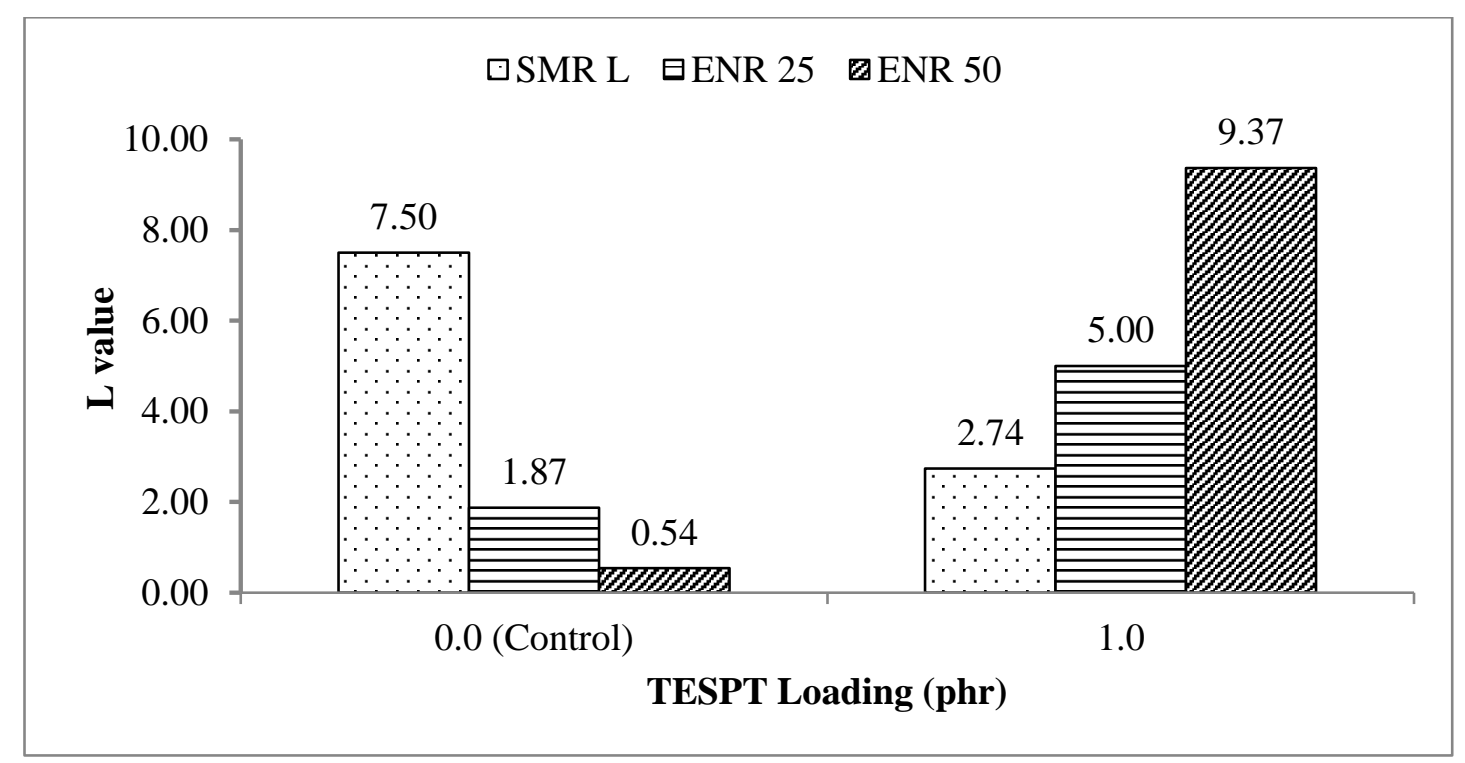

Figure 4. The effect of TESPT on L value of silica-filled SMR-L and ENRs compounds.

\section{Conclusions}

TESPT decreased the minimum torque of silica-filled natural rubber compounds but increased the minimum torques of silica-filled epoxidized natural rubbers compounds. TESPT also increased the maximum torque and torque difference of the silica-filled natural and epoxidized natural rubbers compounds. The plasticizing and compatibilization effects of TESPT were more pronounced to silica-filled natural rubber compounds whilst the curative effect of TESPT was more pronounced to silica-filled epoxidized natural rubbers compounds.

\section{Acknowledgement}

The author would like to thank the Rubber Lab of Universiti Sains Malaysia (USM), Malaysia for providing the research facilities due to carrying out the experiment and making this research work possible.

\section{REFERENCES}

[1] Surya, I., H. Ismail, and A. Azura, Alkanolamide as an accelerator, filler-dispersant and a plasticizer in silica-filled natural rubber copounds. Polymer testing, 2013. 32(8): p. 1313-1321.

[2] Wagner, M., Heat Generation and Rubber-Filler Coupling Bonds. Rubber Chemistry and Technology, 1974. 47(4): p. 697-716.

[3] Wagner, M., Reinforcing silicas and silicates. Rubber chemistry and Technology, 1976. 49(3): p. 703-774. 
[4] Mukhopadyay, R. and S. De, Effect of Vulcanization Temperature and Different Fillers on the Properties of Efficiently Vulcanized Natural Rubber. Rubber chemistry and Technology, 1979. 52(2): p. 263-277.

[5] Fetterman, M.Q., The unique properties of precipitated silica in the design of high performance rubber. Elastomerics, 1984. 116(9): p. 18-31.

[6] Gelling, I., M. Porter, and A. Roberts, Natural rubber science and technology. Eirich, FR, Ed, 1988: p. 367.

[7] Dannenberg, E., Filler choices in the rubber industry. Rubber Chemistry and Technology, 1982. 55(3): p. 860-880.

[8] Lautenschlaeger, F. and K. Edwards, Model Compound Vulcanization-Part V. The Effect of Chemical Additives and Fillers. Rubber chemistry and Technology, 1980. 53(1): p. 2747.

[9] Ranney, M. and C. Pagano, Silane coupling agent effects in ethylene propylene diene terpolymers. Rubber chemistry and Technology, 1971. 44(4): p. 1080-1092.

[10] Gent, A. and E. Hsu, Coupling Reactions of Vinylsilanes with Silica and Poly (ethyleneco-propylene). Macromolecules, 1974. 7(6): p. 933-936.

[11] Fetterman, M., Filler effect on the heat stability of vulcanized elastomeric compositions. Rubber Chemistry and Technology, 1973. 46(4): p. 927-937.

[12] Surya, I., Reinforcement of natural rubber and epoxidized natural rubbers with aminetreated silica. MSc Thesis. 2002, Malaysia: Universiti Sains Malaysia.

[13] Surya, I., H. Ismail, and A. Azura, The comparison of alkanolamide and silane coupling agent on the properties of silica-filled natural rubber (SMR-L) compounds. Polymer testing, 2014.

[14] Akiba, M. and A. Hashim, Vulcanization and crosslinking in elastomers. Progress in polymer science, 1997. 22(3): p. 475-521.

[15] Goerl, U., et al., Investigations into the silica/silane reaction system. Rubber chemistry and Technology, 1997. 70(4): p. 608-623.

[16] 16. Lee, B., Reinforcement of Uncured and Cured Rubber Composites and Its Relationship to Dispersive Mixing-An Interpretation of Cure Meter Rheographs of Carbon Black Loaded SBR and Cis-Polybutadiene Compounds. Rubber Chemistry and Technology, 1979. 52(5): p. 1019-1029. 